J. Amer. Soc. Hort. ScI. 128(2):213-218. 2003.

\title{
Differentiation of Race Specific Resistance to Phytophthora Root Rot and Foliar Blight in Capsicum annuum
}

\author{
Lisa M. Oelke and Paul W. Bosland \\ Department of Agronomy and Horticulture, New Mexico State University, Las Cruces, NM 88003
}

Robert Steiner

University Statistics Center, New Mexico State University, Las Cruces, NM 88003

AdDitional InDEX wORDs. aji, chile, gene-for-gene, pepper, Phytophthora capsici, race resistance

\begin{abstract}
Aвstract. Despite extensive breeding efforts, no pepper (Capsicum annuum L. var. annuum) cultivars with universal resistance to phytophthora root rot and foliar blight (Phytophthora capsici Leon) have been commercially released. A reason for this limitation may be that physiological races exist within $P$. capsici, the causal agent of phytophthora root rot and phytophthora foliar blight. Physiological races are classified by the pathogen's reactions to a set of cultivars (host differential). In this study, 18 varieties of peppers were inoculated with 10 isolates of $P$. capsici for phytophthora root rot, and four isolates of $P$. capsici for phytophthora foliar blight. The isolates originated from pepper plants growing in New Mexico, New Jersey, Italy, Korea, and Turkey. For phytophthora root rot, nine of the 10 isolates were identified as different physiological races. The four isolates used in the phytophthora foliar blight study were all determined to be different races. The identification of physiological races within $P$. capsici has significant implication in breeding for phytophthora root rot and phytophthora foliar blight resistance.
\end{abstract}

Phytophthora capsici Leon. is a soilborne fungal pathogen of worldwide importance and is a major limiting factor in pepper (Capsicum anпиum var. аппиит) production (Bosland and Lindsey, 1991; Ristaino and Johnston, 1999). P. capsici is especially difficult to control because it can cause multiple disease syndromes by infecting the roots, foliage, and fruits of pepper. Chemical control is limited and in most cases ineffective against phytophthora on pepper. Biological control of phytophthora has also been unsuccessful (Goldberg, 1995; Miller et al., 2002).

The development of adapted phytophthora-resistant pepper cultivars is considered to be an essential approach to controlling phytophthora disease. Researchers have bred for phytophthora resistance in peppers for many years but none of the resistant cultivars have been reported to be resistant worldwide (Black and Berke, 1998; Ortega et al., 1995). This may be because the inheritance of resistance is not fully understood. The inheritance of resistance against phytophthora in pepper has been reported to be single-gene, two-gene, or multiple-gene systems (Barksdale et al., 1984; Guerrero and Laborde, 1980; Ortega et al., 1991; Reifschneider et al., 1992; Saini and Sharma, 1978; Smith et al., 1967; Walker and Bosland, 1999). Saini and Sharma (1978) reported that the bell pepper cultivar Waxy Globe carries a single dominant gene for resistance to phytophthora fruit rot. The inheritance of fruit rot resistance was confirmed by a backcross to the susceptible parent resulting in a 1:1 ratio for resistant to susceptible progeny. Both two-gene and multiple-gene systems have been reported for root rot and foliar blight. Smith et al. (1967) were the first to propose the two-gene system. Smith et al. (1967) developed $\mathrm{F}_{1}, \mathrm{~F}_{2}, \mathrm{~F}_{3}$, and $\mathrm{BC}_{1}$ populations from hybridization of three phytophthora-resistant lines and with the susceptible cultivar, Yolo Wonder. Their results indicate the presence of two independent, dominant genes determining resistance to phytophthora root rot. Reifschneider et al. (1992) used the resistant line CNPH148, a line derived from Criollo de Morelos, and

Received for publication 29 Apr. 2002. Accepted for publication 25 Nov. 2002. A contribution of New Mexico Agriculture Experiment Station, New Mexico State University, Las Cruces. two susceptible varieties and confirmed the presence of a twogene system for phytophthora root rot resistance. Criollo de Morelos-334 (CM334) an accession from Mexico is resistant to P. capsici (Guerrero and Laborde, 1980). Ortega et al. (1991) proposed that CM334 has three genes with multiple alleles that determine resistance. These results contradicted previous results by Guerrero and Laborde (1980), who stated two recessive genes provided resistance in CM334. Barksdale et al. (1984) found multiple genes were responsible for resistance to foliar blight and crown rot in pepper by using cultivars, Fyuco and P51, from Argentina and The Netherlands, respectively. Resistance to foliar blight and crown rot was treated as one disease syndrome in this research, not as two separate disease syndromes. Walker and Bosland (1999) found that two independent dominant genes, along with a dominant allele from a third independent gene, separately control resistance to foliar blight and root rot.

There are several possible explanations for the conflicting evidence on the inheritance of resistance even when varieties of similar pedigrees are utilized. One explanation is that different parts of the pepper plant can become infected by $P$. capsici. Each plant part infected can be considered a separate disease syndrome, i.e., root rot, foliar blight, and fruit blight. A second explanation, is that different genes control resistance to the different disease syndromes (Walker and Bosland, 1999). Walker and Bosland (1999) found that different genes were responsible for the inheritance of root rot resistance as compared to foliar blight resistance. Finally, Polach and Webster (1972) and Reifschneider et al. (1986) suggested that physiological races may exist within $P$. capsici.

The objective of these experiments was to investigate the existence of physiological races within P. capsici. A host differential utilizing several varieties of $C$. аппиит that differed in resistance or susceptibility to $P$. capsici was chosen. Isolates of $P$. capsici originating from different geographical regions were selected to screen the host differential. Differences in the virulence of the isolates on specific hosts would confirm the existence of physiological races. 


\section{Materials and Methods}

Plant material. To develop a host differential that would allow for the differentiation of races, 18 accessions of pepper were selected based on prior knowledge about levels of resistance (or lack of resistance) to phytophthora root rot and foliar blight. Pepper accessions used as hosts were 'Adra' (Shamrock Seed Co.), Criollo de Morelos-334 (INIA de Mexico), 'Early Jalapeno' (Seminis), 'Emprapa 431' (F. Reifschneider,Embrapa de Brasilia), 'Floral Gem' (P. Smith, Univ. of California, Davis), NMCA 10052 (INIA de Mexico), NMCA 10158 (CNPhortalicas Brasilia), NMCA 10159 (CNPhortalicas Brasilia), 'Pasilla Salvatierra' (INIA de Mexico), NMCA 10399 (INIA de Mexico), NMCA 10460 (INIA de Mexico), 'NuMex R Naky' (P. Bosland, New Mexico State Univ.), 'Paladin' (Syngenta Seeds, Inc.), 'Phyo' (Syngenta Seeds, Inc.), 'Pm217' (Syngenta Seeds, Inc.), RPP3136 (Syngenta Seeds, Inc.), 'Sonora' (Seminis), and 'TAM Vera Cruz' (B. Villilon, Texas A\&M Univ.). In previous experiments, we found that NMCA 10399 was the most susceptible accession available (data not presented), thus it was used as the susceptible control. The most resistant accession, Criollo de Morelos-334 (CM334), was used as the resistant control.

Seeds of the 18 accessions were sown in commercial peat moss-vermiculite media (Peatlite, Scotts-Sierra Horticultural Products Co., Marysville, Ohio). For each accession, two to three seeds were planted per cell in four-packs (Hummert International, Earth City, Mo.). There were 18 four-packs per tray. The plants were watered as needed, usually twice daily and fertilized when needed (Osmocote 14N-6.2P-11.6K). At the four- to eight-leaf stage, the plants were inoculated with $P$. capsici.

Isolates. Isolates of $P$. capsici were collected from several worldwide locations in order to maximize the diversity of the isolates (Table 1). If previous designations were affiliated with the isolate, its epithet is in parentheses (Table 1). A total of ten isolates were collected and representative samples of each have been deposited in the American Type Culture Collection (ATCC), Manassas, Va. All 10 isolates were used in the root rot experiments, while four of the 10 were used for the foliar blight experiments.

INOCULUM PREPARATION. Inoculum preparation followed the procedures of Bosland and Lindsey (1991) with modifications. Using sterile techniques, plugs $\approx 5 \mathrm{~mm}$ in diameter of the $P$. capsici cultures were transferred from water agar petri plates (100 $\times 15 \mathrm{~mm})$ to $\mathrm{V} 8$ agar plates $(100 \times 15 \mathrm{~mm})$ (Tuite, 1967$)$. The cultures were grown at 27 to $28{ }^{\circ} \mathrm{C}$ in a temperature controlled incubation chamber. At this temperature, in 7 to $10 \mathrm{~d}$ mycelium had covered the petri plates. Instead of using plugs as described in Bosland and Lindsey (1991), the cultures were sliced into 12 equally sized pieces, and transferred to sterile distilled water in $150 \times 15$-mm petri plates. The water was $\approx 1$ to $3 \mathrm{~mm}$ below the top of the agar pieces. The cultures were incubated for 4 to $5 \mathrm{~d}$ at $27^{\circ} \mathrm{C}$. Zoospore production was stimulated by placing the water plate cultures in the refrigerator at $12^{\circ} \mathrm{C}$ for $60 \mathrm{~min}$, and then onto a laboratory bench at room temperature $\left(22\right.$ to $\left.26^{\circ} \mathrm{C}\right)$ for $30 \mathrm{~min}$. The zoospores were collected, and the concentration diluted to the appropriate dilution.

ROOT ROT INOCULATION. Roots of the pepper seedlings were inoculated with $5 \mathrm{~mL}$ of inoculum at 2000 zoospores per $\mathrm{mL}$ following the method of Bosland and Lindsey (1991) with modifications. The plants were inoculated at the four- to eight-leaf stage instead of the four- to six-leaf stage. The plants were scored when the susceptible control (NMCA 10399) plants were primarily at the 7 and 9 rating following the rating system of Bosland and Lindsey (1991). The rating system was as follows: $1=$ no symptoms; $3=$ the roots of the plant are brown or the plant is wilting; $5=$ crown of the plant is brown, but not girdled; $7=$ the crown of the plant is girdled; $9=$ the stem of the plant is girdled up from the crown or the plant is dead. Symptoms that were between ratings were given intermediate ratings of $2,4,6$, or 8 . Plants with a rating of 1 were considered resistant. All other ratings were considered susceptible. The proportion of plants that were resistant to each isolate was calculated. The proportion of plants within a variety resistant to each isolate was used in the analysis. The proportion of resistant plants of each variety was compared to the proportion of resistant plants in the resistant control, CM334.

Foliar blight inoculation. The leaves of the pepper plants were inoculated for foliar blight following the procedures detailed by Alcantara and Bosland (1994) with modifications. Each plant had three leaves inoculated with $45 \mu \mathrm{L}$ of inoculum at 40,000 zoospores per $\mathrm{mL}$, instead of 100 to $200 \mu \mathrm{L}$ of inoculum as described in Alcantara and Bosland (1994). The plants were scored 7 to $10 \mathrm{~d}$ after inoculation, instead of $5 \mathrm{~d}$ to clearly distinguish between a susceptible and a resistant plant. Alcantara and Bosland (1994) utilized a rating system from 1 to 9, based on necrotic lesion size. In this study, the plants were rated as susceptible when any inoculated leaf had a visible lesion or disintegration of the leaf tissue had occurred. Both are symptoms of successful colonization of $P$. capsici on pepper. Accessions that were considered resistant had an incompatible or an immunity response to inoculation. The proportion of pepper plants resistant to each isolate was used in the analysis.

EXPERIMENTAL DESIGN. The root rot and foliar blight experiments were designed as unbalanced incomplete block designs because several isolates were inoculated at the same time. A complete randomization design of the experiment could not be

Table 1. Isolate designations, epithet, origin and sources of Phytophthora capsici isolates.

\begin{tabular}{lll}
\hline \hline Designation & Origin & Source \\
\hline PWB-24 & New Mexico & P. Bosland, New Mexico State University \\
PWB-53 (Hensel) & New Jersey & S. Johnston, Rutgers University \\
PWB-54 (Hallock) & New Jersey & S. Johnston \\
PWB-57 (Probasco) & New Jersey & S. Johnston \\
PWB-60 (Pc6011) & New Mexico & S. Fernandez, New Mexico State University \\
PWB-66 (Pc6022) & New Mexico & R. Creamer, New Mexico State University \\
PWB-71 (P16) & Italy & P. Belletti, University of Turin, Italy \\
PWB-73 (DEM-1) & Turkey & Cakir, Akinez University, Turkey \\
PWB-74 (Yenikoy) & Turkey & Cakir \\
PWB-75 (Youngyang Subi) & Korea & Byung-Soo Kim, Kyugpook National University, Korea \\
\hline
\end{tabular}

${ }^{\mathrm{z}}$ Isolates used in foliar blight tests. 
used because of the high likelihood of cross contamination by the isolates. Each block contained one replication of each isolate. Each of the ten isolates was replicated at least three times. Within the unbalanced incomplete block design, a split-plot experimental design was used with the isolate as the whole plot and the varieties as the subplots randomized within isolates. Each variety was planted in a four-pack and a tray held 18 four-packs, therefore 18 varieties or subplots were randomly place within each whole plot (isolate).

Statistical analysis. The data for the root rot and foliar experiments were analyzed using SAS System for Windows (SAS Institute, Inc., 1999). The block was considered as random, while isolates and varieties as fixed variables. Therefore, PROC MIXED procedure with the RANDOM option was used to analyze the data (SAS Institute, Inc., 1999). PROC GLM does not calculate the correct standard errors for pairwise differences in data sets with unplanned missing values. However, PROC MIXED is able to calculate the correct standard errors (Little et al., 1996). The PROC MIXED calculates F values for the fixed effects based on residual variances estimated by the residual (restricted) maximum likelihood method (REML). The PROC MIXED method analyzed the entire data set for the isolate by variety interaction. For the second part of the analysis, the data set was split by isolate. The PROC MIXED method was performed within the isolate. Within each isolate, the least square means of proportion of resistant plants were calculated for the fixed effect, variety. For each isolate, the varieties were compared to the resistant standard control, CM334, for a total of 17 comparisons per isolate. The proportion of resistant plants was determined from 8 to 12 plants. Each of these comparisons was run at an alpha of 0.05. In these experiments, the type II error was more important than the type I family-wise error. The type II error was important because when breeding for disease resistance it is better to classify a variety as susceptible when it is actually resistant, than to classify a variety as resistant when it is actually susceptible. A type I error is the probability of declaring a null hypothesis false when it is true, i.e., declaring a variety different from the resistant control when it as resistant as CM334. Controlling for type II error in this study controls the probability of declaring a truly susceptible variety as resistant.

\section{Results}

Phytophthora root rot. Analysis of variance indicated that the isolate, the variety, and the isolate $\times$ variety interaction for phytophthora root rot were very highly significant $(P<0.0001)$ (Table 2). The data were split by isolate giving a total of 10 data sets. The least square means of the proportion of resistant plants for each variety to an isolate was calculated and ranged from -0.0536 to 1.0677 (Table 3).

Any variety that was significantly different from the resistant control, CM334, was considered susceptible to that tested isolate. The accessions CM334, NMCA 10158, and NMCA 10159 were resistant to all 10 isolates used in this investigation (Table 4). Conversely, NMCA 10399 was susceptible to all 10 isolates tested. 'Emprapa 431' and 'Pm217' were resistant to 9 of the 10

Table 2. Analysis of variance table for phytophthora root rot.

\begin{tabular}{|c|c|c|c|c|}
\hline Source & $\begin{array}{c}\text { Numerator } \\
\text { df }\end{array}$ & $\begin{array}{c}\text { Denominator } \\
\text { df }\end{array}$ & $F$ value & $P>\mathrm{F}$ \\
\hline Isolate & 9 & 56 & 32.35 & $<0.0001$ \\
\hline Variety & 17 & 1094 & 127.00 & $<0.0001$ \\
\hline Isolate $\times$ variety & 153 & 1094 & 5.91 & $<0.0001$ \\
\hline
\end{tabular}

Table 3. Least square means of proportion of plants of each variety resistant to phytophthora root rot for a given isolate of Phytophthora capsici.

\begin{tabular}{|c|c|c|c|c|c|c|c|c|c|c|}
\hline \multirow[b]{2}{*}{ Variety } & \multicolumn{10}{|c|}{ Isolate } \\
\hline & 24 & 73 & 74 & 66 & 60 & 71 & 53 & 57 & 75 & 54 \\
\hline$\overline{\mathrm{CM} 334^{\mathrm{Z}}}$ & 1.0000 & 1.0000 & 0.9236 & 1.0000 & 1.0000 & 1.0000 & 1.0000 & 1.0000 & 1.0000 & $\overline{1.0000}$ \\
\hline NMCA 10158 & 0.9974 & 0.9815 & 0.9896 & 1.0000 & 0.9837 & 1.0677 & 1.0033 & 0.9986 & 0.9714 & 0.9990 \\
\hline NMCA 10159 & 0.8993 & 0.9778 & 0.9446 & 0.9504 & 0.9286 & 1.0564 & 1.0023 & 0.9643 & 1.0000 & 1.0000 \\
\hline Emprapa 431 & $0.8020^{*}$ & 0.9600 & 0.9970 & 1.0000 & 1.0000 & 1.0000 & 0.9827 & 0.8571 & 1.0000 & 1.0024 \\
\hline $\operatorname{Pm} 217$ & $0.6475^{*}$ & 0.9016 & 0.9595 & 0.8000 & 1.0049 & 0.9167 & 0.9074 & 0.9103 & 0.9286 & 1.0000 \\
\hline Floral Gem & $0.0964^{*}$ & $0.7460^{*}$ & 0.9308 & 0.8333 & 0.9095 & 0.9018 & 1.0000 & 1.0011 & 1.0036 & 0.9966 \\
\hline NMCA 10460 & $0.2577^{*}$ & $0.6815^{*}$ & 0.9167 & 0.8873 & 0.9838 & $0.5122^{*}$ & 0.9841 & 1.0011 & 1.0091 & 1.0000 \\
\hline Early Jalapeno & $0.0127^{*}$ & $0.2139^{*}$ & 0.8596 & $0.5464^{*}$ & $0.5000^{*}$ & $0.3194^{*}$ & 0.9778 & 0.8818 & 1.0000 & 1.0000 \\
\hline Phyo & $0.1026^{*}$ & $0.1125^{*}$ & $0.5136^{*}$ & $0.4422^{*}$ & $0.2168^{*}$ & $0.5000^{*}$ & 0.9333 & 0.7684 & 1.0000 & 0.9966 \\
\hline RPP3136 & $0.0417^{*}$ & $0.0786^{*}$ & $0.4470^{*}$ & $0.0 .5102^{*}$ & $0.6032^{*}$ & $0.5000^{*}$ & 0.8944 & 0.8272 & 1.0000 & 1.0000 \\
\hline NMCA 10052 & $0.0443^{*}$ & $0.0000^{*}$ & $0.4070^{*}$ & $0.4052^{*}$ & $0.3029^{*}$ & 0.6614 & $0.2269^{*}$ & $0.6457^{*}$ & 0.7558 & 0.9590 \\
\hline Paladin & $0.0325^{*}$ & $0.0293^{*}$ & $0.6300^{*}$ & $0.4056^{*}$ & $0.5181^{*}$ & $0.1250^{*}$ & 0.8988 & $0.6489^{*}$ & 1.0000 & 1.0000 \\
\hline Adra & $0.0833^{*}$ & $0.0125^{*}$ & $0.0897^{*}$ & $0.1673^{*}$ & $0.0326^{*}$ & $0.3750^{*}$ & $0.4328^{*}$ & $0.1456^{*}$ & 1.0000 & 0.9566 \\
\hline Sonora & $0.0000^{*}$ & $0.0000^{*}$ & $0.0061^{*}$ & $0.2204^{*}$ & $0.1250^{*}$ & $0.1937^{*}$ & $0.0185^{*}$ & $0.3010^{*}$ & $0.7258^{*}$ & 0.8552 \\
\hline TAM Vera Cruz & $0.0952^{*}$ & $0.1000 *$ & $0.0966^{*}$ & $0.3393^{*}$ & $0.0357^{*}$ & $0.4143^{*}$ & $0.0714^{*}$ & $0.0000^{*}$ & $0.7422^{*}$ & 0.9106 \\
\hline Pasilla Salvatierra & $-0.0536^{*}$ & $0.0000 *$ & $0.2311^{*}$ & $0.4280^{*}$ & 0.9265 & 0.7555 & $-0.0123^{*}$ & $0.3453^{*}$ & $0.4305^{*}$ & $0.5247^{*}$ \\
\hline NuMex R Naky & $0.0028^{*}$ & $0.1000^{*}$ & $-0.0030^{*}$ & $0.1429^{*}$ & $0.1691^{*}$ & $0.3011^{*}$ & $0.0000^{*}$ & $0.1803^{*}$ & $0.5905^{*}$ & $0.7798^{*}$ \\
\hline NMCA 10399 & $0.1127^{*}$ & $0.1667^{*}$ & $0.0922^{*}$ & $0.3508^{*}$ & $0.1659^{*}$ & $0.3750^{*}$ & $-0.0075^{*}$ & $0.0011^{*}$ & $0.3145^{*}$ & $0.3212^{*}$ \\
\hline df & 197 & 134 & 166 & 95 & 82 & 43 & 119 & 92 & 88 & 78 \\
\hline
\end{tabular}

${ }^{\mathrm{z} C M} 334$ = Criollo de Morelos-334.

*Statistically different from the resistant control (CM334), $P=0.05$. 
Table 4. Phenotypic response of the 18 host differential to 10 isolates of Phytophthora capsici for root rot.

\begin{tabular}{|c|c|c|c|c|c|c|c|c|c|c|}
\hline \multirow[b]{2}{*}{ Variety } & \multicolumn{10}{|c|}{ Isolate } \\
\hline & 24 & 73 & 74 & 66 & 60 & 71 & 53 & 57 & 75 & 54 \\
\hline$\overline{\mathrm{CM} 334^{\mathrm{z}}}$ & $\mathrm{R}^{\mathrm{y}}$ & $\mathrm{R}$ & $\mathrm{R}$ & $\mathrm{R}$ & $\mathrm{R}$ & $\mathrm{R}$ & $\mathrm{R}$ & $\mathrm{R}$ & $\mathrm{R}$ & $\mathrm{R}$ \\
\hline NMCA 10158 & $\mathrm{R}$ & $\mathrm{R}$ & $\mathrm{R}$ & $\mathrm{R}$ & $\mathrm{R}$ & $\mathrm{R}$ & $\mathrm{R}$ & $\mathrm{R}$ & $\mathrm{R}$ & $\mathrm{R}$ \\
\hline NMCA 10159 & $\mathrm{R}$ & $\mathrm{R}$ & $\mathrm{R}$ & $\mathrm{R}$ & $\mathrm{R}$ & $\mathrm{R}$ & $\mathrm{R}$ & $\mathrm{R}$ & $\mathrm{R}$ & $\mathrm{R}$ \\
\hline Emprapa 431 & S & $\mathrm{R}$ & $\mathrm{R}$ & $\mathrm{R}$ & $\mathrm{R}$ & $\mathrm{R}$ & $\mathrm{R}$ & $\mathrm{R}$ & $\mathrm{R}$ & $\mathrm{R}$ \\
\hline $\operatorname{Pm} 217$ & S & $\mathrm{R}$ & $\mathrm{R}$ & $\mathrm{R}$ & $\mathrm{R}$ & $\mathrm{R}$ & $\mathrm{R}$ & $\mathrm{R}$ & $\mathrm{R}$ & $\mathrm{R}$ \\
\hline Floral Gem & S & $\mathrm{S}$ & $\mathrm{R}$ & $\mathrm{R}$ & $\mathrm{R}$ & $\mathrm{R}$ & $\mathrm{R}$ & $\mathrm{R}$ & $\mathrm{R}$ & $\mathrm{R}$ \\
\hline NMCA 10460 & S & $\mathrm{S}$ & $\mathrm{R}$ & $\mathrm{R}$ & $\mathrm{R}$ & $\mathrm{S}$ & $\mathrm{R}$ & $\mathrm{R}$ & $\mathrm{R}$ & $\mathrm{R}$ \\
\hline Early Jalapeno & $\mathrm{S}$ & $\mathrm{S}$ & $\mathrm{R}$ & $\mathrm{S}$ & S & $\mathrm{S}$ & $\mathrm{R}$ & $\mathrm{R}$ & $\mathrm{R}$ & $\mathrm{R}$ \\
\hline Phyo & $S$ & $\mathrm{~S}$ & $\mathrm{~S}$ & S & S & S & $\mathrm{R}$ & $\mathrm{R}$ & $\mathrm{R}$ & $\mathrm{R}$ \\
\hline RPP3136 & $\mathrm{S}$ & $\mathrm{S}$ & S & $\mathrm{S}$ & S & $\mathrm{S}$ & $\mathrm{R}$ & $\mathrm{R}$ & $\mathrm{R}$ & $\mathrm{R}$ \\
\hline NMCA 10052 & $\mathrm{~S}$ & $\mathrm{~S}$ & S & $\mathrm{S}$ & $S$ & $\mathrm{R}$ & $\mathrm{S}$ & $\mathrm{S}$ & $\mathrm{R}$ & $\mathrm{R}$ \\
\hline Paladin & $\mathrm{S}$ & $\mathrm{S}$ & $S$ & $\mathrm{~S}$ & $S$ & $\mathrm{~S}$ & $\mathrm{R}$ & $\mathrm{S}$ & $\mathrm{R}$ & $\mathrm{R}$ \\
\hline Adra & $\mathrm{S}$ & $\mathrm{S}$ & $S$ & $\mathrm{~S}$ & S & $\mathrm{S}$ & $\mathrm{S}$ & $\mathrm{S}$ & $\mathrm{R}$ & $\mathrm{R}$ \\
\hline Sonora & $\mathrm{S}$ & $\mathrm{S}$ & S & $\mathrm{S}$ & $S$ & $\mathrm{~S}$ & S & $\mathrm{S}$ & $\mathrm{S}$ & $\mathrm{R}$ \\
\hline TAM Vera Cruz & $\mathrm{S}$ & $\mathrm{S}$ & $S$ & $\mathrm{~S}$ & $S$ & $\mathrm{~S}$ & $S$ & $\mathrm{~S}$ & $\mathrm{~S}$ & $\mathrm{R}$ \\
\hline Pasilla Salvatierra & $\mathrm{S}$ & $\mathrm{S}$ & $S$ & $\mathrm{~S}$ & $\mathrm{R}$ & $\mathrm{R}$ & $S$ & S & $\mathrm{S}$ & $\mathrm{S}$ \\
\hline NuMex R Naky & $\mathrm{S}$ & $\mathrm{S}$ & S & $\mathrm{S}$ & $\mathrm{S}$ & $\mathrm{S}$ & $S$ & S & $\mathrm{S}$ & $\mathrm{S}$ \\
\hline NMCA 10399 & $\mathrm{~S}$ & $\mathrm{~S}$ & $\mathrm{~S}$ & $\mathrm{~S}$ & $S$ & $\mathrm{~S}$ & $S$ & $\mathrm{~S}$ & $\mathrm{~S}$ & $\mathrm{~S}$ \\
\hline
\end{tabular}

${ }^{\mathrm{z} C M} 334=$ Criollo de Morelos-334.

${ }^{\mathrm{y}} \mathrm{R}=$ resistant, $\mathrm{S}=$ susceptible.

isolates and only susceptible to isolate PWB-24. 'Floral Gem' was resistant to eight of the isolates and susceptible to isolates PWB-24 and PWB-73. NMCA 10460 was resistant to seven of the isolates and susceptible to isolates PWB-42, PWB-73, and PWB-71. 'Early Jalapeno' was resistant to isolates PWB-53, PWB-54, PWB-57, PWB-74, and PWB-75. 'Phyo' and 'RPP3136' were resistant to isolates PWB-53, PWB-54, PWB-57, and PWB75. NMCA 10052 was resistant to isolates PWB-54, PWB-71, and PWB-75. 'Paladin' was resistant to isolate PWB-53, PWB75, and PWB-54. 'Adra' was resistant to isolates PWB-54 and PWB-75. 'Pasilla Salvatierra' was resistant to isolates PWB-60 and PWB-71. 'Sonora' and 'TAM Vera Cruz' were resistant to isolate PWB-54.

Only three varieties were found to be resistant to isolate PWB24 from New Mexico (NMCA 10158, NMCA 10159, and CM334). Isolate PWB-73 from Turkey resulted in one more resistant variety than isolate PWB-24. 'Pm217' was resistant to PWB-73. The isolate with the most resistant responses was PWB-54 from New Jersey with only 'Pasilla Salvatierra', 'NuMex R Naky' and NMCA 10399 susceptible to the isolate. Isolate PWB-75 from Korea resulted in two additional susceptible responses, to 'Sonora' and 'TAM Vera Cruz', than PWB-54. Isolates PWB-53 and PWB-57, both from New Jersey, differed in the host differential by one variety. Isolate PWB- 53 resulted in a susceptible response from NMCA 10052. Isolates PWB-60 and PWB-66 had the same responses to the 18 varieties, and therefore did not differentiate into different races with this differential. Isolates PWB-60 and PWB-66 were both from New Mexico.

Рhytophthora foliar blight. The analysis of variance for the isolate and for the variety for the phytophthora foliar blight experiment were very highly significant $(P<0.0001)$ (Table 5). The analysis of variance for the isolate $\times$ variety interaction was significant $(P<0.03)$ (Table 5). The least square means of the proportion of resistant plants ranged from 0.0000 to 1.0000 (Table 6). CM334, NMCA 10158, 'Phyo' and 'PM217' were resistant to the four isolates tested (Table 7). NMCA 10159, NMCA 10460, 'Floral Gem', 'Emprapa 431' and 'Paladin' were susceptible to isolate PWB-73 and resistant to PWB-24, PWB74, and PWB-57, 'Adra', 'Early Jalapeno', NMCA 10052, and 'RPP3136' were susceptible to isolates PWB-24 and PWB-73, and resistant to isolates PWB-57 and PWB-74. 'NuMex R Naky', NMCA 10399, 'Pasilla Salvatierra', 'Sonora', and 'TAM Vera Cruz' were susceptible to all four of the isolates tested.

\section{Discussion}

Flor (1946) demonstrated that a gene-for-gene interaction exists between a host and a pathogen. The cloning and characterization of plant resistance genes and pathogen avirulence genes has largely confirmed this model (Nishimura and Somerville, 2002). Stakman and Piemeisal (1917) introduced the term physiologic race, which is often abbreviated as race, to mean an isolate that caused a differential resistance response among host genotypes. In some Phytophthora species, for example P. infestans of potato (Solanum tuberosum L.) and P. sojae Kauf. and Gerde. of soybeans (Glycine max L. Merr.) (Gallegly, 1970), races are well documented.

The experiments reported here have clearly demonstrated that

Table 5. Analysis of variance for foliar blight of Phytophthora capsici.

\begin{tabular}{lcccc}
\hline \hline & Numerator & Denominator & & \\
Source & $\mathrm{df}$ & $\mathrm{df}$ & $\mathrm{F}$ value & \\
\hline Isolate & 4 & 348 & 15.67 & 36.53 \\
Variety & 17 & 348 & 1.38 & $<0.0001$ \\
Isolate $\times$ variety & 68 & 348 & 0.001 \\
& & & 1.0341 \\
\hline
\end{tabular}


Table 6. Least square means of proportion of plants of each variety resistant to foliar blight by each isolate of Phytophthora capsici.

\begin{tabular}{lcccc}
\hline \hline & \multicolumn{4}{c}{ Isolate } \\
\cline { 2 - 5 } Variety & 24 & 73 & 74 & 57 \\
\hline CM334 & 1.0000 & 1.0000 & 1.0000 & 1.0000 \\
NMCA 10158 & 0.9960 & 0.9842 & 0.9513 & 0.9217 \\
NMCA 10159 & 0.9960 & 0.5953 & 0.9513 & 0.9217 \\
NMCA 10460 & 0.8626 & 0.5675 & 0.9513 & 0.9217 \\
Phyo & 0.9583 & 1.0000 & 0.9167 & 0.8472 \\
Pm217 & 0.9583 & 0.8556 & 0.8750 & 0.7917 \\
Floral Gem & 0.8639 & 0.5833 & 0.9583 & 0.7778 \\
Emprapa 431 & 0.9960 & 0.6509 & 0.9513 & 0.9217 \\
Paladin & 0.7381 & $0.4881^{*}$ & 0.7917 & 0.9722 \\
Early Jalapeno & $0.5139^{*}$ & $0.3917^{*}$ & 0.9167 & 0.7917 \\
NMCA 10052 & $0.4960^{*}$ & $0.4286^{*}$ & 0.9513 & 0.9217 \\
RPP3136 & $0.4325^{*}$ & $0.5119^{*}$ & 0.9583 & 1.0000 \\
Adra & $0.4028^{*}$ & $0.3770^{*}$ & 0.8125 & 0.6139 \\
NuMex R Naky & $0.5028^{*}$ & $0.0000^{*}$ & $0.4167^{*}$ & $0.3472^{*}$ \\
Pasilla Salvatierra & $0.1747^{*}$ & $0.0333^{*}$ & $0.1532^{*}$ & $0.1797^{*}$ \\
Sonora & $0.0417^{*}$ & $0.0333^{*}$ & $0.3333^{*}$ & $0.3194^{*}$ \\
Tam Vera Cruz & $0.1488^{*}$ & $0.2222^{*}$ & $0.4375^{*}$ & $0.3194^{*}$ \\
NMCA 10399 & $0.1075^{*}$ & $0.0000^{*}$ & $0.0417^{*}$ & $0.2083^{*}$ \\
df & 68 & 65 & 70 & 64 \\
\hline
\end{tabular}

${ }^{\mathrm{z} C M} 334$ = Criollo de Morelos-334.

*Statistically different from the resistant control (CM334), $P=0.05$.

physiological races exist within $P$. capsici based on distinct reactions to the $C$. annuum differentials. These differential responses indicated the absence of an avirulence gene in one isolate as compared to the presence of an avirulence gene in another isolate. The lack of an avirulence gene results in a susceptible response (Flor, 1946). The presence of an avirulence gene is needed to identify at least one resistance gene in the resistant host.

It has been proposed that the resistance genes for root rot and for foliar blight disease syndromes evolved separately. Foliarattacking Phytophthora species have pronounced appressoria, but root-attacking species lack conspicuous appressoria (Irwin et al., 1997). Walker and Bosland (1999) found that phytophthora foliar blight resistance genes are independent of root rot resistance genes. Therefore, attempts to breed peppers resistant to
Table 7. Variety responses to four isolates of Phytophthora capsici for foliar blight.

\begin{tabular}{|c|c|c|c|c|}
\hline \multirow[b]{2}{*}{ Variety } & \multicolumn{4}{|c|}{ Isolate } \\
\hline & 24 & 73 & 74 & 57 \\
\hline CM334 & $\mathrm{R}^{\mathrm{y}}$ & $\mathrm{R}$ & $\mathrm{R}$ & $\mathrm{R}$ \\
\hline NMCA 10158 & $\mathrm{R}$ & $\mathrm{R}$ & $\mathrm{R}$ & $\mathrm{R}$ \\
\hline Phyo & $\mathrm{R}$ & $\mathrm{R}$ & $\mathrm{R}$ & $\mathrm{R}$ \\
\hline PM217 & $\mathrm{R}$ & $\mathrm{R}$ & $\mathrm{R}$ & $\mathrm{R}$ \\
\hline NMCA 10159 & $\mathrm{R}$ & S & $\mathrm{R}$ & $\mathrm{R}$ \\
\hline NMCA 10460 & $\mathrm{R}$ & S & $\mathrm{R}$ & $\mathrm{R}$ \\
\hline Floral Gem & $\mathrm{R}$ & S & $\mathrm{R}$ & $\mathrm{R}$ \\
\hline Emprapa 431 & $\mathrm{R}$ & S & $\mathrm{R}$ & $\mathrm{R}$ \\
\hline Paladin & $\mathrm{R}$ & S & $\mathrm{R}$ & $\mathrm{R}$ \\
\hline Early Jalapeno & $\mathrm{S}$ & $S$ & $\mathrm{R}$ & $\mathrm{R}$ \\
\hline NMCA 10052 & $S$ & $S$ & $\mathrm{R}$ & $\mathrm{R}$ \\
\hline RPP3136 & S & S & $\mathrm{R}$ & $\mathrm{R}$ \\
\hline Adra & S & S & $\mathrm{R}$ & S \\
\hline NuMex R Naky & S & S & $\mathrm{S}$ & S \\
\hline Pasilla Salvatierra & S & S & $\mathrm{S}$ & $\mathrm{S}$ \\
\hline Sonora & S & S & $\mathrm{S}$ & 'S \\
\hline TAM Vera Cruz & S & S & S & S \\
\hline NMCA 10399 & S & S & $\mathrm{S}$ & S \\
\hline
\end{tabular}

${ }^{\mathrm{z} C M} 334$ = Criollo de Morelos-334.

${ }^{y_{R}}=$ resistant, $\mathrm{S}=$ susceptible.

phytophthora root rot and phytophthora foliar blight must treat both disease syndromes as independent and incorporate both resistance systems.

The fact that PWB-60 and PWB-66 were unable to be differentiated into separate physiological races illustrates the importance of the host differential to identify physiological races. Additional varieties included in the host differential may allow differentiation of these two isolates into separate races. It is also important to point out that a host differential should consist of varieties that are useful to researchers in a given region. A different set of hosts for the differential may be more useful in Korea or Turkey. A host differential is most useful when varieties are representative of the growing area and can differentiate physiological races endemic to the area.

Criollo de Morelos-334 (CM334), the resistant control, is still

Table 8. Physiological race assignments for phytophthora root rot and foliar blight disease syndromes of Phytophthora. capsici.

\begin{tabular}{|c|c|c|c|}
\hline Designation & $\begin{array}{l}\text { Race } \\
\text { assignment }\end{array}$ & $\begin{array}{l}\text { Other } \\
\text { designation }\end{array}$ & Source \\
\hline \multicolumn{4}{|c|}{ Phytophthora root rot } \\
\hline PWB-24 & Race 1 & $\mathrm{~N} / \mathrm{A}^{\mathrm{z}}$ & New Mexico \\
\hline PWB-73 & Race 2 & DEM-1 & Turkey \\
\hline PWB-74 & Race 3 & Yenikov & Turkey \\
\hline PWB-60, 66 & Race 4 & Pc6011 & New Mexico \\
\hline PWB-71 & Race 5 & P16 & Italy \\
\hline PWB-53 & Race 6 & Hensel & New Jersey \\
\hline PWB-57 & Race 7 & Probasco & New Jersey \\
\hline PWB-75 & Race 8 & Youngyang Subi & Korea \\
\hline PWB-54 & Race 9 & Hallock & New Jersey \\
\hline \multicolumn{4}{|c|}{ Phytophthora foliar blight } \\
\hline PWB-24 & Race 1 & N/A & New Mexico \\
\hline PWB-73 & Race 2 & DEM-1 & Turkey \\
\hline PWB-74 & Race 3 & Yenkikoy & Turkey \\
\hline PWB-57 & Race 4 & Probasco & New Jersey \\
\hline
\end{tabular}

${ }^{\mathrm{z}}$ None available. 
a good source of resistance against phytophthora root rot and phytophthora foliar blight. CM334 was resistant to all ten isolates tested for root rot and all four isolates for foliar blight. However, race resistance genes were not associated with CM334 in this study because CM334 was not susceptible to any of the isolates used. An isolate virulent on CM334 is needed to be able to give a race resistance designation to $\mathrm{CM} 334$. This result was not surprising because previous researchers have shown that when CM334 is hybridized to a susceptible parent the progeny do segregate for susceptible and resistant offspring. It is plausible that CM334 possesses some unique physiological attributes that give it such a wide range of resistance. An approach using recombinant inbred lines might elucidate the genetic composition of this unique accession. Nevertheless, the other hosts in the differential satisfactory identified specific races in $P$. capsici.

The five most virulent races in the root rot study were the three isolates from New Mexico and the two isolates from Turkey. The New Jersey isolates were the least virulent in this study. Because isolates of $P$. capsici in New Jersey are less virulent than isolates in New Mexico, peppers grown in New Jersey may not require as many race resistance genes as peppers grown in New Mexico. Race resistant genes can be pyramided into pepper cultivars the same way race resistant genes are pyramided into soybeans and potatoes (Erwin and Ribeiro, 1991).

Knowing that physiological races exist in the $P$. capsici-C. annuum interaction will assist breeders in developing phytophthora-resistant cultivars. While from a global perspective it may be formidable to breed for universal resistance to $P$. capsici on pepper, it may be possible to breed for resistance to isolates found in specific growing regions. For instance, isolates from New Jersey in this study had fewer virulence genes than isolates from New Mexico. Thus breeders may be able to release resistant cultivars for New Jersey sooner than for the New Mexico growing region. However, the presence of both mating types of $P$. capsici in some regions such as New Mexico may make durable resistance difficult.

\section{Literature Cited}

Alcantara, T.P. and P.W. Bosland. 1994. An inexpensive disease screening technique for foliar blight of chile pepper seedlings. HortScience 29:1182-1183.

Barksdale, T.H., G.C. Papvizas, and S.A. Johnston. 1984. Resistance to foliar blight and crown rot of pepper caused by Phytophthora capsici. Plant Dis. 68:506-509.

Black, L.L. and T. Berke. 1998. Breeding for phytophthora resistance in pepper. Xth Eucarpia Mtg. Genet. Breeding Capsicum and Eggplant, Avignon, France.

Bosland,P.W. and D.L. Lindsey. 1991. A seedling screen for phytophthora root rot of pepper, Capsicum annuum. Plant Dis. 75:1048-1050.

Erwin, D.C. and O.K. Ribeiro. 1991. Phytophthora capsici, p. 262-268.
In: Phytophthora diseases worldwide. Amer. Phytopathol. Soc., St. Paul, Minn.

Flor, H.H. 1946. Genetics of pathogenicity in Melampsora lini. J. Agr. Res. 73:335-357.

Gallegly, M.E. 1970. Genetics of phytophthora. Phytopathology 60:11351140.

Goldberg, N.P. 1995. Chile Pepper Diseases. N.M. Agr. Ext. Sta., College Agr. Home Econ. Circ. 549.

Guerrero-Monreno, A. and J.A. Laborde. 1980. Current status of pepper breeding for resistance to Phytophthora capsici in Mexico, p. 52-56. In: Synop. IVth Mtg. Capsicum Working Group of EUCARPIA, Wageningen, The Netherlands, 14-16 Oct.

Irwin, J.A., A.R. Crawford, and A. Drenth. 1997. The origins of phytophthora species attacking legumes in Australia. Adv. Bot. Res. 24:431-456.

Little, R.C., G.A. Milliken, W.W. Stroup, and R.D. Wolfinger. 1996. SAS system for mixed models, SAS Inst. Inc. Cary, N.C.

Miller, S.A., M.L. Miller, L. Ivey, and J. Mera. 2002. Reponses of pepper cultivars and experimental breeding lines to phytophthora blight, 2001. Biological and cultural tests for control of plant disease. (Online) Rpt. 17:V16. DOI:1094/BC17. Amer. Phytopathol. Soc., St. Paul, Minn.

Nishimura, M. and S. Somerville. 2002. Resisting attack. Science 295:20322033.

Ortega, R.G., C. Palazon-Espanol, and J. Cuartero-Zueco. 1991. Genetics of resistance to Phytophthora capsici in the pepper line 'SCM-334'. Plant Breed. 107:50-55.

Ortega, R.G., C. Palazon-Espanol, and J. Cuartero-Zueco. 1995. Interactions in the pepper-Phytophthora capsici system. Plant Breed. 111:7477.

Polach, F.J. and R.K. Webster. 1972. Identification of strains and inheritance of pathogenicity in Phytophthora capsici. Phytopathology 62:20 26.

Reifschneider, F.J.B., A.C. Café-Filho, and A.M. Rego. 1986. Factors affecting expression of resistance in pepper (Capsicum annuum) to blight caused by Phytophthora capsici in screening trials. Plant Pathol. 35:451456.

Reifschneider, F.J.B., L.S. Boiteux, P.T. Della Vecchia, J.M. Poulos, and N. Kurdoda. 1992. Inheritance of adult-plant resistance to Phytophthora capsici in pepper. Euphytica 62:45-49.

Ristaino, J.B. and S.A. Johnston. 1999. Ecologically based approaches to management of phytophthora blight of bell pepper. Plant Dis. 83:1080 1089.

Tuite, J. 1967. Plant pathological methods. Fungi and bacteria. Burgess Publ., Minneapolis, Minn.

Saini, S.S. and P.P. Sharma. 1978. Inheritance of resistance to fruit rot (Phytophthora capsici Leon.) and induction of resistance in bell pepper (Capsicum annuum L.). Euphytica 27:721-723.

SAS Institute, Inc. 1999. Version 8.00. Cary, N.C.

Smith, P.G., K.A. Kimble, R.G. Grogan, and A.H. Millett. 1967. Inheritance of resistance in peppers to phytophthora root rot. Phytopathology 57:377-379.

Stakman, E.C. and F.J. Piemeisal. 1917. Biologic forms of Puccina graminis on cereals and grasses. J. Agr. Res. 10:429-495.

Walker, S.J. and P.W. Bosland. 1999. Inheritance of phytophthora root rot and foliar blight resistance in pepper. J. Amer. Soc. Hort. Sci. 124:14-18. 